\title{
半側空間無視による黄斑分割の可能性
}

\author{
馬場 育子1）・仲泊 聡1) 2) · 北原 健二 ${ }^{2)}$ \\ 1) 神奈川リハビリテーション病院 \\ 2) 東京慈恵会医科大学眼科学講座
}

\section{Does unilateral spatial neglect cause macular splitting?}

\author{
Ikuko Baba $^{1)}$, Satoshi Nakadomari ${ }^{1)}{ }^{2)}$, Kenji Kitahara ${ }^{2)}$ \\ 1) Kanagawa Rehabilitation Hospital \\ ${ }^{2)}$ Department of Ophthalmology, The Jikei University school of Medicine
}

\begin{abstract}
要 約
同名半盲は、その範囲と形状によって、原因病巣の部位診断がある程度可能であるが、MRI等で 検出された損傷部位と、視野欠損のパターンが、常に一致するとは限らない。一方、半側空間無視 があるとそれが原因で同名半盲と同様の検査結果となる可能性がある。その場合、あたかも黄斑分 割を伴った完全な同名半盲になることが推定される。

そこで我々は、同名半盲患者の視野検査で、完全型であるか否かに着目し、これと半側空間無視 との間の相関を統計学的に検討した。対象は、Goldmann視野検查を施行した患者のうち、同名半 盲を認めた 94 名であった。これらの症例の完全型の有無と半側空間無視の有無について集計し $2 \times$ 2 分割表分析にて相関を解析した。その結果、 $\chi^{2}=10.648 、 \mathrm{p}<0.01 て ゙$ 高い相関が認められた。半 側空間無視は、右脳損傷患者に比較的多く見られる神経学的症候であるが、視野検查の際に半側空 間無視の特性を取り除くことは難しい。したがって、視野検查の結果を判定する場合、半側空間無 視の有無について、十分考慮しなくてはならないものと考える。
\end{abstract}

別冊請求先（テ243-0121）神奈川県厚柿七沢516

神奈川リハビリテーション病院 馬 場 育 子

Tel. $046-249-2528$

Key words : 同名半盲, 黄斑分割, 半側空間無視, 視野検査, homonimous hemianopsia, macular splitting, unilateral spatial neglect, perimetry 


\begin{abstract}
We examined the statistical relation between unilateral spatial neglect (USN) and macular splitting in the visual field. The pattern of homonymous hemianopsia can often, but not always, be used to help identify lesions. If homonymous hemianopsia caused by USN can be diagnosed, then the visual field defect must have macular splitting. We attempted to confirm this supposition and analyzed the correlation between USN and macular splitting statistically with the $\chi^{2}$ test. Our subjects were 94 patients (63 men and 31 women; average age, 61.2 years) with homonymous hemianopsia on Goldmann perimetry. Thirty -four patients had USN and 17 had macular splitting. Twelve of the 34 patients with USN also had macular splitting. This result suggests a statistically significant correlation between USN and macular splitting ( $\chi 2$ value, 10.648: $\mathrm{p}<0.01$ ). USN is a neurological sign present in some patients with injury to the right cerebral hemisphere. Excluding the effects of USN on perimetry is difficult. Therefore, the possibility of USN must be considered when the visual field is examined.
\end{abstract}

\section{I. 緒 言}

視交叉より後方の視路損傷によって生じる視 野障害では、両眼の同側視野に狭窄を生じる同 名半盲になる。同名半盲は、左右、上下のどこ に生じるかによって、また、左右眼での調和性 の有無や黄斑分割であるか黄斑回避であるかに よって、ある程度の部位診断が可能であること が知られている。しかし、MRI等で検出された 損傷部位と視野欠損のパターンが、常に一致す るとは限らないということも、臨床上しばしば 経験されることである。一方、頭頂葉を中心と した損傷によって生じる半側空間無視は、自ら の正中正面より左（ときに右）側の物を無視す る症候であり、重症例ではからだの片側をよく ぶつけるとか、食事の時片方の半分を食べ残す など日常生活上で様々な支障をきたすことも少 なくない。程度が軽い場合でも、検査上模写で 半側を描かなかったり、水平線分を二等分する 際に大きく二等分点が片側へ偏るなどの所見が 認められる ${ }^{1-3)}$ 。半側空間無視の原因はいまの ところ明らかではないが、視野が正常であって もこの症状がみられることがあるため、半盲が その原因ではないものと考えられている。この ように同名半盲は、片側の視路障害で生じ、半 側空間無視は同名半盲から生じるものではない。 しかし、半側空間無視が原因で、視野検査にお
いては同名半盲と診断される可能性は否定でき ない。眼科臨床で通常行われている視野検査は、 身体の正面にある固視点を凝視したままの固視 点周囲の視野における光点の検出とその応答と してのボタン押しや言語などの行動が必要にな る。もし左半側空間無視のある患者がこの検査 をした場合、固視点の左に出る点は、身体の正 面からの左側でもあり、これを無視してしまっ てボタン押しをしないということがあるかもし れない。したがって、半側空間無視があるとそ れが原因で同名半盲と同様の検査結果となる可 能性がある4，5)。その場合、あたかも黄斑分割 を伴った完全型の同名半盲のような視野検査結 果になることが推定される。今回、我々は、こ のような黄斑分割を伴い、1/4盲でもなく、周辺 視野に残存視野を認めない完全な同名半盲を 「完全型同名半盲」と呼び、同名半盲患者の視 野検査結果のうち、この完全型であるかどうか に着目し、これと患者の半側空間無視の症状の 有無との間に相関があるかどうかについて統計 学的に検討した。

\section{II. 対象および方法}

対象は、平成 11 年 4 月 7 日から平成 12 年 7 月 7 日に七沢病院眼科を受診し、Goldmann視野 検査を施行した患者のうち、同名半盲を認めた 
94名（男性63名、女性31名）で、年齢は32～88 歳（平均61.2歳）であった。なおGoldmann視野 検査は、すべて一人の視能訓練士によって行わ れた。これらの症例の視野のタイプ、視力、病 巣、原因疾患の種類、発症から検査までの期間 の各々において完全型同名半盲と半側空間無視 の有無を集計した。さらに全デー夕における完 全型同名半盲と半側空間無視の有無について $2 \times 2$ 分割表分析を行い、これらの相関を検討 した。

視野のタイプは、欠損の左右、上下に加え、 完全型であるかどうかで分類した。視力は、左 右眼各々0.5 logMAR以上であるか未満であるか と左右眼での差が 0.3 (logMAR) 以上あるかど うかで分類した。病巣は、左右半球と主病巣の 部位（後頭葉、頭頂葉、側頭葉、被穀、視床、 多発、その他）で分類した。原因疾患は、頻度 の多かった脳梗塞と脳出血とそれ以外で分類し た。発症から検査までの期間は、1 1 月以内、 $1 \sim 2$ ヶ月、 $2 \sim 3$ ヶ月、 $3 \sim 6$ ヶ月、 6 ヶ月 以上に分類した。また、半側空間無視の判定は、 眼科検查に前後して行われた複数の神経内科医 と臨床心理士による机上検査に基づいた判定を カルテ上で参照した。

\section{III. 結 果}

\section{1 ）対象のプロフィール}

対象の視野のタイプごとの人数を表 1 に示す。 今回の調查では、左同名半盲が 52 名 $(55 \%)$ 、 右同名半盲は 41 名 $(44 \%)$ であった。このうち、 完全型同名半盲は 17 名 $(18 \%) 、$ 半側空間無視
表 1 . 視野のタイプごとの人数

\begin{tabular}{|c|c|c|c|c|}
\hline $\begin{array}{c}\text { 視野欠損 } \\
\text { の左右 }\end{array}$ & 上下 & $\begin{array}{l}\text { 合計 } \\
\text { (人) }\end{array}$ & $\begin{array}{c}\text { 完全型 } \\
\text { 同名半盲 } \\
(\mathcal{N}\end{array}$ & $\begin{array}{c}\text { 半側空間 } \\
\text { 無視 } \\
(\mathrm{N})\end{array}$ \\
\hline \multirow{4}{*}{ 右側 } & 両 & 19 & 4 & 2 \\
\hline & 上 & 5 & 0 & 0 \\
\hline & 下 & 17 & 0 & 0 \\
\hline & 合計 & 41 & 4 & 2 \\
\hline \multirow{4}{*}{ 左側 } & 両 & 28 & 13 & 20 \\
\hline & 上 & 7 & 0 & 3 \\
\hline & 下 & 17 & 0 & 9 \\
\hline & 合計 & 52 & 13 & 32 \\
\hline \multirow{4}{*}{ 両側 } & 両 & 1 & 0 & 0 \\
\hline & 上 & 0 & 0 & 0 \\
\hline & 下 & 0 & 0 & 0 \\
\hline & 総計 & 94 & 17 & 34 \\
\hline
\end{tabular}

は34名（36\%）であった。

対象の矯正視力においては、0.5 logMAR以上 の視力低下を示した対象が188眼中21眼であっ た。これらには各々眼底疾患や緑内障などの眼 疾患が認められた。また、1名は認知障害のた め視野検査は可能であったものの視力検査が不 能であった。左右眼の視力に0.3 (logMAR) 以 上の差が認められた対象は10名であった。右視 力が低下した 12 名中完全型同名半盲は 2 名で、 左視力が低下した 9 名中完全型同名半盲は 2 名 であった。これらは、全体の中に占める完全型 同名半盲の割合とほほ一致するので、完全型同 名半盲と視力低下との相関はないものと考えら れた。

また対象の病巣とその割合を図 $1-1$ に、病 巣毎の完全型同名半盲と半側空間無視をきたし た割合を図 $1-2$ に示す。完全型同名半盲は頭 頂葉と後頭葉の損傷に多く、半側空間無視は頭

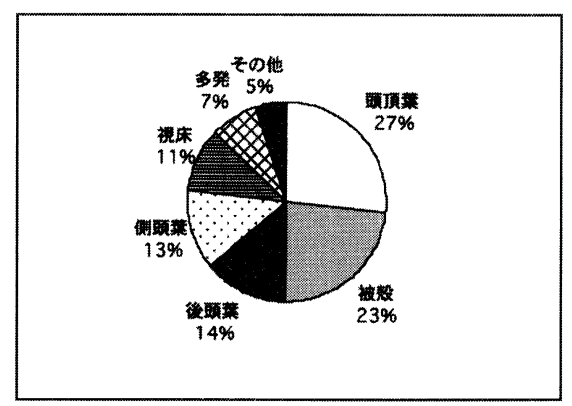

$1-1$

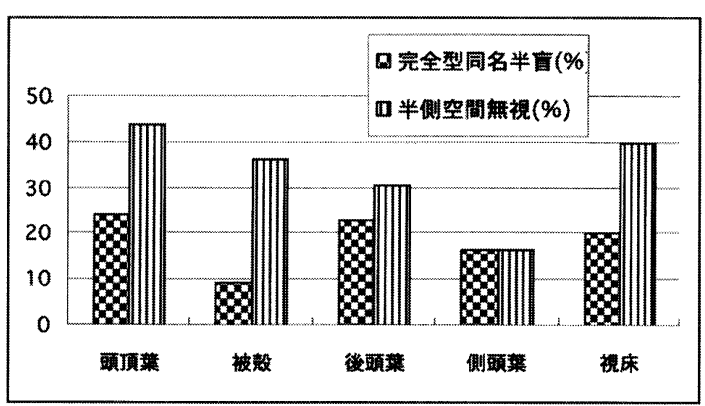

$1-2$

図 1.1）病巣の割合

2 ）病巣毎の完全型同名半盲と半側空間無視をきたした割合 


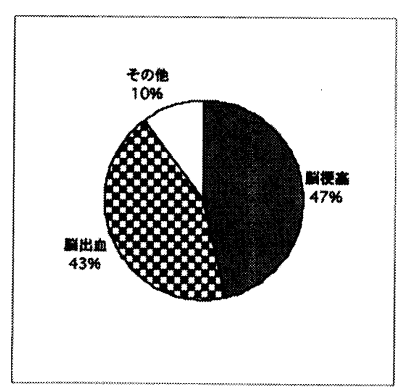

$2-1$

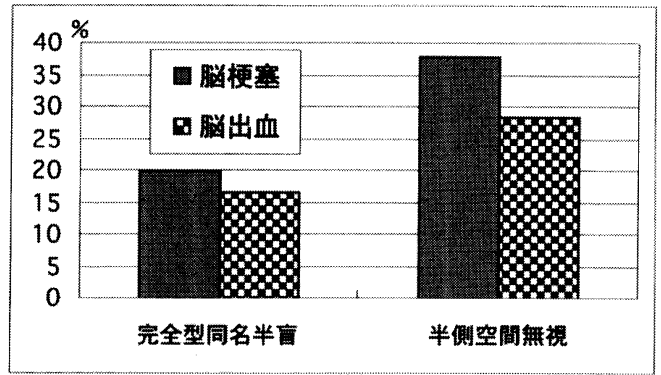

$2-2$

図 2，1）原因疾患の割合

2 ）原因疾患毎の完全型同名半盲と半側空間無視をきたした割合

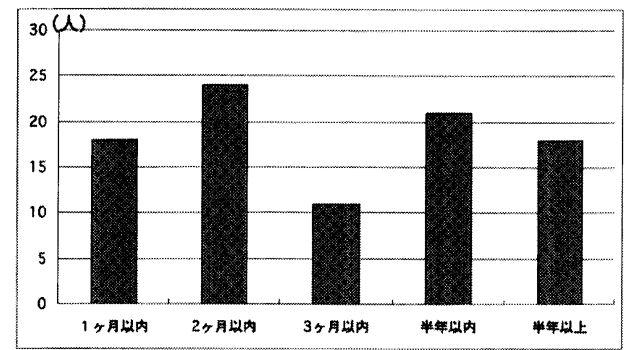

$3-1$

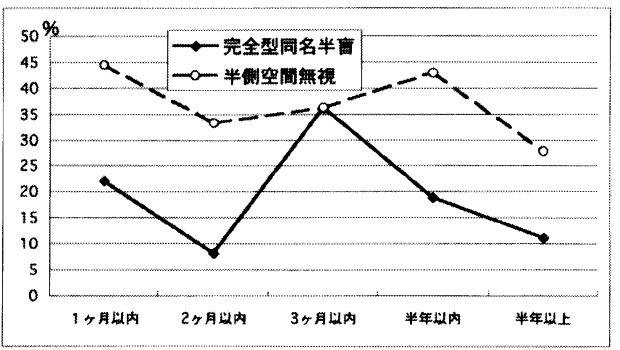

$3-2$

図 3.1）発症から検査までの期間における人数

2 ）期間毎の完全型同名半盲と半側空間無視をきたした割合

表 2 . 完全型同名半盲と半側空間無視と相関 半側空間無視 (人)

\begin{tabular}{|c|c|c|c|c|}
\hline & & 無 & 有 & 合計 \\
\hline \multirow{3}{*}{$\begin{array}{l}\text { 完全型同名 } \\
\text { 半盲（人） }\end{array}$} & 無 & 55 & 22 & 77 \\
\hline & 有 & 5 & 12 & 17 \\
\hline & 合計 & 60 & 34 & 94 \\
\hline
\end{tabular}

$$
\chi 2=10.648 \quad p<0.01
$$

頂葉と視床の損傷に多い傾向があった。さらに 対象の原因疾患とその割合を図 2-1に、原因 疾患毎の完全型同名半盲と半側空間無視をきた した割合を図2-2に示す。脳出血と脳梗塞では、 これらの出現頻度に多きな差はみられなかった。

次に対象の発症から検查までの各期間におけ る人数を図 $3-1$ に示す。また、図 $3-2$ に経 過期間毎の完全型同名半盲と半側空間無視をき たした割合の推移を示す。発症からの経過時間 によって、特にこれらが生じやすいという時期 はみられなかった。
2 ) 完全型同名半盲と半側空間無視との相関 完全型同名半盲と半側空間無視との相関をみ るために、 $2 \times 2$ 分割表にデー夕をまとめた （表 2 ）。これを用いて $\chi^{2}$ 検定を行ったところ、 $\chi^{2}=10.648 、 \mathrm{p}<0.01 て ゙ 、$ 完全型同名半盲と半 側空間無視の間には高い相関が認められた。

\section{IV. 考按}

視野のタイプは、今回の調査では左同名半盲 がやや多かった。そして、左同名半盲52名のう ち完全型同名半盲は 13 名で、右同名半盲の 41 名 中 4 名に比べ、明らかに多いことが分かる。こ の点が本調査で最も注目すべき点である。視力、 原因疾患、発症からの経過期間による各視野パ ターンの出現頻度に、特に目立った特徵を示す ものはなかった。しかし、病巣では、明らかに 右半球のものの中に黄斑分割が多く、これは左 同名半盲に黄斑分割が多いことと呼応していた (図 4 )。

半側空間無視は、自らの正中正面より左（時 


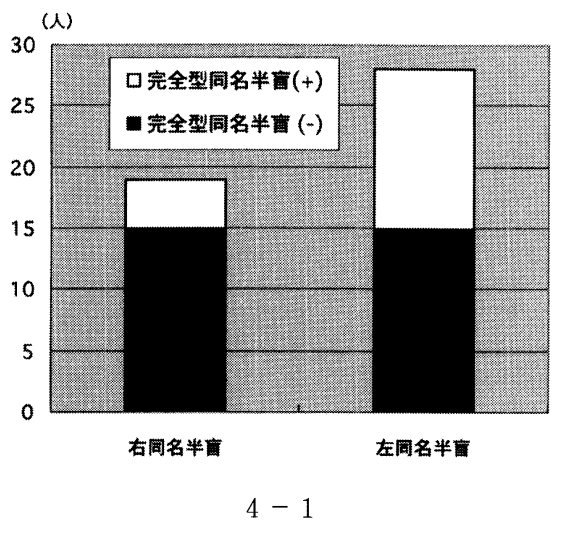

図 4.視野のタイプ

に右）側の物を無視する症候で、かつ右半球病 変に明らかに発症頻度が高い神経症候である。 もし、この症候により黄斑回避や $1 / 4$ 盲が完全型 の同名半盲として視野計測されているとしたら、 当然、左同名半盲に完全型同名半盲がみられや すいことが考えられる。我々は、この仮説を検 証するために、完全型同名半盲と半側空間無視 に着目し、これらの相関関係について統計学的 に検討した結果、有意水準 1\%でこれらの間に 高い相関関係を確認した。

今回の解析で考慮しなければならない点は、 視野測定が一人の検査員によって行われたこと かもしれない。このことは、視野検查施行時の 応答点決定での判定基準が同一であるという点 から、結果を比較する上での信頼性を高いもの にしている。その反面、検者の癖を取り除くこ とができないという久点を同時に含んでいる。 ただし、今回の左右差に関しては、同じ検者に 左右で判定基準が違うということは考えられな w。

一方、半側空間無視の判定が一定でないとい うことに問題があるかもしれない。限られた眼 科診察の中で、半側空間無視の心理検査を時間 をかけて行うことは困難であり、また検者が不 馴れであるということもあって、今回は眼科検 査に前後して行われた複数の神経内科医と臨床 心理士による判定をカルテ上で参照し、これら を半側空間無視の有無の判定基準とした。した がって、各患者に用いられた検査バッテリーは
様々で、それを判定した医師の診断基準も各医 師によりまちまちである。しかし、本調査で示 されたように明らかな有意差が認められている ので、このことが、今回認めた黄斑分割と半側 空間無視のとの相関を覆す根拠にはならないと 考える。

また、実際に検査を行った印象では、半側空 間無視のある患者は半側空間無視のみられない 患者に比べて特に固視不良だったように感じら れた。そして、固視不良例が多かったにもかか わらず、反応は正中子午線の左右で明確に異な っていた。これまでに半側空間無視の責任病巣 の近傍に運動維持困難の責任病巣が存在してお り、两者が同時に損傷されている症例が多いた めに固視不良となることが推定されている ${ }^{6)}$ 。 そして固視不良である場合、反応の再現性は悪 くなるのが普通であるが、半側空間無視の患者 では正中子午線を境にした応答が比較的明瞭と なる特徴がみられた。

同名半盲において、黄斑分割であるか黄斑回 避であるかは重要な所見である。しかし、今回 示したように黄斑分割の中で完全型同名半盲で ある場合は、半側空間無視による異常が入り込 んでいる可能性が否定できない。したがって、 視野検査の結果を判断する場合、特にその結果 が完全型である場合には、半側空間無視の有無 について十分考慮しなくてはならないものと考 える。

\section{参考文献}

1) 石合純夫：半側空間無視. 神経心理学 11： 85-94, 1995.

2 ) 武田克彦: 半側空間無視. 神経心理学 11 : 95-99, 1995.

3 ）石合純夫：視空間認知障害の評価法. 臨床リ 八別冊/高次脳機能障害のリハビリテーショ ン : 135-141, 1995.

4) 大八木智仁, 他：半側空間無視および同名半 盲を伴ったAlzheimer病の一例. 神経眼科 17増補：46, 2000.

5 ）仲泊 聡, 他：Functional MRIにより同名半 盲が半側空間無視によって生じたものと考え 
られた 1 症例. 日本眼科学会雑誌：202, 1996.

6 ）平林一, 他：運動維持困難. 臨床リ八, 別
冊/高次脳機能障害のリハビリテーション： 67-71, 1995. 